\title{
Assessing Potential Scour Using the South Carolina Bridge-Scour Envelope Curves
}

\section{The Issue}

Bridge-scour equations presented in the Federal Highway Administration Hydraulic Engineering Circular No. 18 (HEC-18; Richardson and Davis, 2001) reflect the current state-of-the practice for predicting scour at bridges. Although these laboratory-derived equations provide an important resource for assessing scour potential, there is a measure of uncertainty when applying these equations to field conditions. The uncertainty and limitations have been acknowledged by laboratory researchers (Breusers and others, 1977; Ettema and others, 1998; Melville and Coleman, 2000) and confirmed in field investigations (Mueller and Wagner, 2005; Benedict and others, 2006; Benedict and Caldwell, 2006, 2009).

Because of the uncertainty associated with bridge-scour equations, HEC-18 (Richardson and Davis, 2001) recommends that engineers evaluate the computed scour depths obtained from the equations and modify the resulting data if they appear unreasonable. Perhaps the best way to evaluate the reasonableness of predicted scour is to compare it to field measurements of historic scour. Historic field data show scour depths resulting from high flows and provide a reference for evaluating predicted scour. It is rare, however, that such data are available at or near a site of interest, making the evaluation of predicted scour as compared to field data difficult if not impossible. Realizing the value of historic scour measurements, the U.S. Geological Survey (USGS), in cooperation with the South Carolina Department of Transportation (SCDOT), conducted a series of three field investigations (Benedict, 2003; Benedict and Caldwell, 2006, 2009, 2012) to collect historic scour data with the goal of understanding regional trends of scour at riverine bridges in South Carolina.

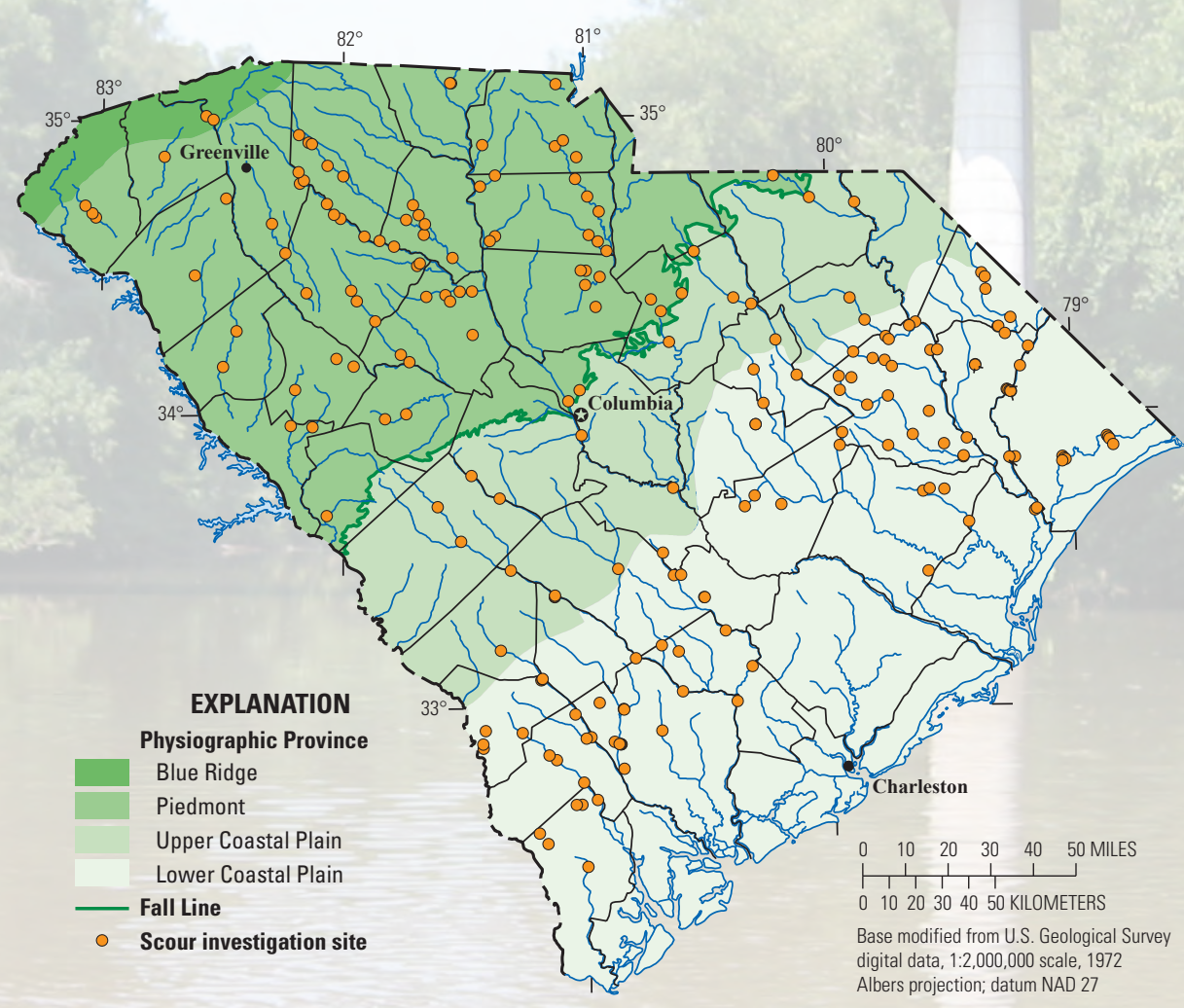

Figure 1. Location of physiographic provinces and bridge-scour study sites in South Carolina.

Historic scour measurements, including measurements of clear-water abutment, contraction, and pier scour, as well as live-bed contraction and pier scour, were made at more than 200 bridges (fig. 1). These field investigations provided valuable insights into regional scour trends and yielded regional bridge-scour envelope curves that can be used as supplementary tools for assessing all components of scour at riverine bridges in South Carolina (examples shown in figures 2 and 3 ).

The application and limitations of these envelope curves were documented in four reports (Benedict, 2003; Benedict and Caldwell, 2006, 2009, 2012). Because each report addresses different components of bridge scour, it was recognized that there was a need to develop an integrated procedure for applying the envelope curves to help assess scour potential at riverine bridges in South Carolina. The result of that effort is detailed in Benedict and others (2016) and summarized in this fact sheet.

\section{Study Objectives}

A primary objective of the investigation by Benedict and others (2016) was to synthesize the findings of previously published reports into a single guidance manual providing an integrated procedure for applying the South Carolina bridge-scour envelope curves. In addition to the guidance manual, a companion spreadsheet was developed to facilitate application of this integrated procedure. Additional objectives of the 
investigation were to (1) evaluate the South Carolina bridge-scour envelope curves by comparing them with bridgescour data outside of South Carolina from previously published sources, (2) develop 500-year recurrence-interval flow bridge-scour envelope-curve coefficients for each scour component, and (3) merge the three previously published databases (Benedict, 2003; Benedict and Caldwell, 2006, 2009) into a format that later could be incorporated into an integrated Web-based GIS application such as StreamStats (Ries and others, 2008) to provide a user-friendly format for accessing the data.

\section{Benefits}

The results of this investigation can benefit the SCDOT by (1) evaluating the South Carolina regional bridge-scour envelope curves with other sources of field data providing verification of the envelope curves; (2) developing an integrated procedure for utilizing the South Carolina regional bridge-scour envelopes to assess scour potential at riverine bridges in South Carolina; and
(3) developing a spreadsheet that will automate the computational components of the integrated procedure to help evaluate scour potential at a given bridge in a consistent and timely manner. Although the scour assessing procedures developed in this investigation are directly applicable to South Carolina, they may be applicable to streams in other States where stream characteristics are similar to those in South Carolina.

The investigation also can benefit the USGS and science, in general, by investigating the trends of scour within field data collected in South Carolina and other States and, thus, providing increased understanding of general and regional trends in scour. Additionally, the procedures developed for utilizing the regional envelope curves for assessing scour potential in South Carolina could be applicable to other States with similar regional characteristics. For States with regional characteristics that are distinctly different from South Carolina, the procedures may not be directly applicable but can still provide some guidance and insights into scour trends in general.
Figure 2. Comparison of the South Carolina livebed pier-scour envelope curve with the envelope curve developed from selected field data from the National Bridge Scour Database (from Benedict and Caldwell, 2009). Dashed lines are projections.

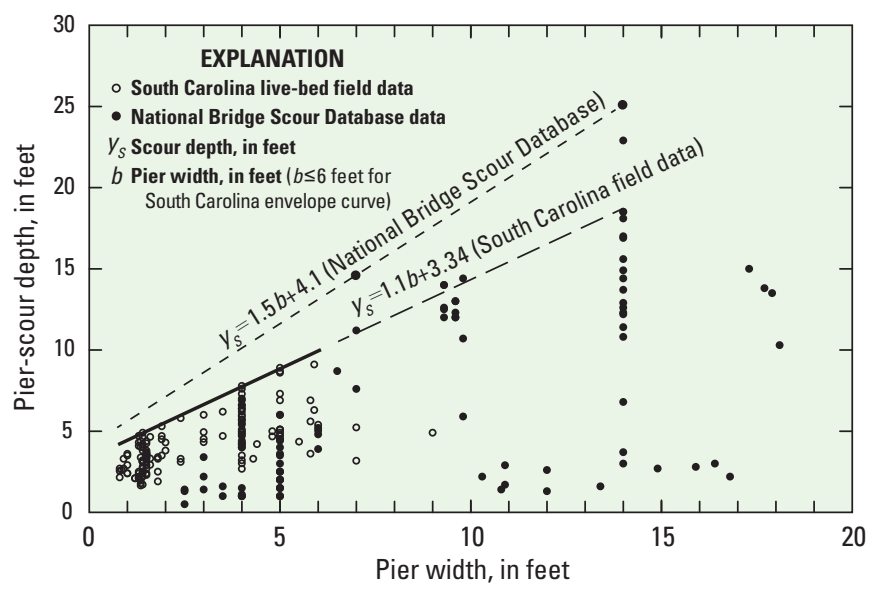

Figure 3. The South Carolina Piedmont clearwater abutment-scour envelope curve with respect to the embankment length blocking flow (from Benedict, 2003).

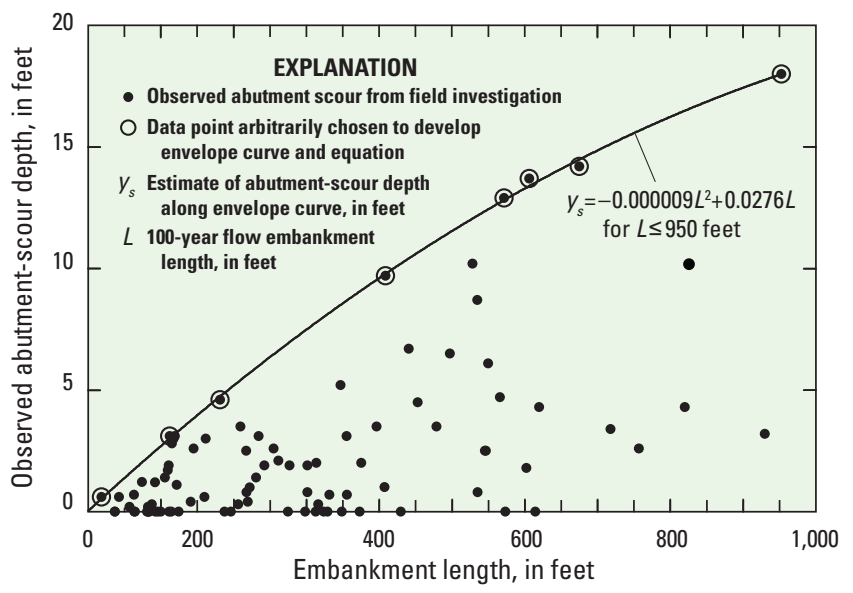

ISSN 2327-6932 (online) http://dx.doi.org/10.3133/fs20163065

\section{References Cited}

Benedict, S.T., 2003, Clear-water abutment and contraction scour in the Coastal Plain and Piedmont Provinces of South Carolina, 1996-99: U.S. Geological Survey Water-Resources nvestigations Report 03-4064, 137 p.

Benedict, S.T., and Caldwell, A.W., 2006, Development and evaluation of clear-water pier and contraction scour envelope curves in the Coastal Plain and Piedmont Provinces of South Carolina: U.S. Geological Survey Scientific Investigations Report 2005-5289, 98 p.

Benedict, S.T., and Caldwell, A.W., 2009, Development and evaluation of live-bed pier and contraction scour envelope curves in the Coastal Plain and Piedmont Provinces of South Carolina: U.S. Geological Survey Scientific Investigations Report 2009-5099, 108 p.

Benedict, S.T., and Caldwell, A.W., 2012, Modification of selected South Carolina bridge-scour envelope curves: U.S. Geological Survey Scientific Investigations Report 2012-5029, 37 p.

Benedict, S.T., Deshpande, N., Aziz, N.M., and Conrads, P.A., 2006, Trends of abutment-scour prediction equations applied to 144 field sites in South Carolina: U.S. Geological Survey Open-File Report 2003-295, 150 p.

Benedict, S.T., Feaster, T.D., and Caldwell, A.W., 2016, The South Carolina bridge-scour envelope curves: U.S. Geological Survey Scientific Investigations Report 2016-5121, 96 p., accessed September 28, 2016, http://dx.doi.org/10.3133/sir20165121.

Breusers, H.N.C., Nicollet, G., and Shen, H.W., 1977, Local scour around cylindrical piers: Journal of Hydraulic Research, v. 15, no. 3, p. 211-252.

Ettema, Robert, Melville, B.W., and Barkdoll, Brian, 1998, Scale effect in pier-scour experiments: Journal of Hydraulic Engineering, v. 124 , no. 6 , p. $639-642$

Melville, B.W., and Coleman, S.E., 2000, Bridge scour: Highlands, Colo., Water Resources Publications, $550 \mathrm{p}$.

Mueller, D.S., and Wagner, C.R., 2005, Field observations and evaluations of streambed scour at bridges: Federal Highway Administration, Publication FHWA-RD-03-052, 122 p.

Richardson, E. V., and Davis, S. R., 2001, Evaluating scour at bridges (4th ed.): Federal Highway Administration Hydraulic Engineering Circular No. 18: Federal Highway Administration Publication No. FHWA NHI 01-001, 378 p.

Ries, K.G., III, Guthrie, J.D, Rea A.H., Steeves, P.A., and Stewart, D.W., 2008, StreamStats: A water resources web application: U.S. Geological Survey Fact Sheet 2008-3067, 6 p., available at http://pubs.usgs.gov/fs/2008/3067/.

By Stephen T. Benedict, Toby D. Feaster, and Andral W. Caldwell

For more information, please contact:

Director, South Atlantic Water Science Center U.S. Geological Survey

720 Gracern Road

Columbia, SC 29210

http://www.usgs.gov/water/southatlantic/ 